UDC 316.323.6

JEL Classification: J24; J28; M51

http://doi.org/10.21272/mmi.2019.2-25

Grzegorz Ignatowski,

D.Sc., Social Sciences Academy, Poland

Bartlomiej Stopczynski,

D.Sc., Social Sciences Academy, Poland

Joanna Trebska,

D.Sc., University of Lodz, Poland

\title{
PARADOX OF NEPOTISM IN ENTERPRISES IN POLAND AND UKRAINE: SOCIAL CAPITAL PERSPECTIVE
}

\begin{abstract}
The aim of the article is to analyse the phenomenon of nepotism, its effects in small and medium enterprises in Poland and Ukraine and their negative impact on social capital. Systematization literary sources and approaches for solving the problem of nepotism indicate that it is quite a common phenomenon in central and east European countries. Nepotism caused a lot of negative impact on organizations. It means, that in the organization, where nepotism is common employees have less motivation, job satisfaction. Their commitment to the organization is lower. They are also less efficient due to the selection of less capable candidates for the job or position. According to literature, on the other hand, nepotism could sometimes have a positive impact on family-owned companies. The article contains a review of the literature on social capital, nepotism and its effects, followed by an analysis of the results of quantitative research aimed at expanding knowledge about the problem of nepotism, determining its scope in Polish and Ukrainian enterprises, as well as its evaluation. The methodological tool of the research was a survey. Questionnaires were distributed to 691 working part-time students of private universities in Poland. The research was conducted from February to May 2019. The paper presents the results of an empirical analysis which showed that both nepotism and closely related cronyism are common phenomena in Poland and Ukraine. It should be pointed out that they are more common in Ukraine. Both phenomena have a negative impact on satisfaction, motivation and work, commitment and trust among employees. One of the important effects of favouring people in the workplace is also reduced the social capital of the company. The results of the research can be useful for managers. Social capital is one of the important elements significant for the development of a company, and nepotism affects it negatively. The conducted research can be used as an aid in creating and reorganizing transparent processes related to the employment of staff and effective personnel management in the organization.

Keywords: nepotism, cronyism, social capital, recruitment preferences.
\end{abstract}

Introduction. Nepotism is a phenomenon usually assessed negatively and identified with organizational pathologies. The literature of the subject shows that it may lead to limiting the effectiveness of the employee's work, weakening the trust of employees and their morale, and reducing their loyalty to the company. These factors reduce the social capital of the organization, whose value is the effect of interpersonal and social links contributing to the implementation of the assigned tasks (Cobb, 2012). On the other hand, nepotistic practices are often found in small and medium-sized family businesses. In addition, according to certain researchers, nepotism can also have positive effects in different societies and enterprises. Therefore, nepotism can take on paradoxical features, not only in family businesses. Namely, nepotistic practices can be seen as bringing negative effects, as well as an activity that can be considered understandable. Bearing in mind the effects of nepotism, it should be noted that the phenomenon is still not widely discussed, we encounter some deficiency of empirical research on the very concept of nepotism and its effects, especially among people from Central and Eastern Europe who are increasingly employed in enterprises operating in western countries. The aim of the article is to analyse the phenomenon of nepotism, its effects in small and medium enterprises in Polish and Ukraine and their negative impact on social capital. The implementation of this goal in this article is possible through a research program, which is based on a comparison of the phenomenon of

Cite as: Ignatowski, G., Stopczynski, B., \& Trebska, J. (2019). Paradox of Nepotism in Enterprises in Poland and Ukraine: Social Capital Perspective. Marketing and Management of Innovations, 2, 295-313. http://doi.org/10.21272/mmi.2019.2-25 
nepotism in Polish and Ukrainian societies. The result of quantitative research will be the identification and stratification of factors related to nepotism. This will allow to gain in-depth knowledge of nepotism and to determine the direction for further research. The research results and their analysis will also have practical value. They can be used by small and medium-sized business owners when making rational decisions related to the employment of family members, setting standards when hiring employees and the knowledge of the issue itself.

Literature Review. Nepotism is one of the forms of favouring people in the workplace. The most frequent form of nepotism is the employment of family members by the business owner. However, nepotism is not limited to family businesses and can occur in any organization. Strictly speaking, nepotism means unfairly awarding lucrative work for members of one's own family, in a situation where the employing person has power (Crowther, 1998). Broader and more accurate definitions say that nepotism means to favour family members, spouses or their own children when hiring them as new employees. Nepotism also includes situations when preferences are given to family members who are already employed. It is about subsequent decisions, such as supporting the career path, allocation of the job to do or remuneration (Fisher, 2005). Sometimes nepotism is understood in a more general sense. In this case, the term includes situations when anyone employed in the organization has family ties with someone working in the same organization and this has some impact on his recruitment (Padgett et al., 2015). In this paper, the term «nepotism» is understood as unfair employment of members own family and supporting their development path, as well as granting preferential remuneration, inadequate to their workload. In English, the term nepotism appears in the 17th century, and its roots should be seen in the Latin word «nepos», which means a grandson or nephew. It was borrowed directly from the French «nepotisme» stemming from the early Italian word «nepotism». In its original meaning, whose testimony can be found in English literature as early as 1670, nepotism referred to the practices of popes and other church dignitaries, who showed special support for grandchildren or other family members in granting high positions (Barnhart, 1999).

Nepotism should not be confused with cronyism, which is also one of the forms favouring people in the workplace. Cronyism is the practice of unfairly hiring one's friends in high positions, by people who have power in a given organization. This term is most likely derived from the word «crony», which means a very close friend or companion (Crowther, 1998). The roots of this term are seen in the seventeenthcentury university slang. Then the term meant a «friend of long-standing». The term 'cronyism', which appears in English in 1840, had a positive meaning. It was used to name «the ability or desire to make friends». Only in 1952, when the administration of American president Harry Truman was accused of appointing friends in the American government, regardless of their qualifications, it took on a negative connotation. Thus, the word neutral and positive in its content began to take on a negative meaning. The term «crony» has taken on a derogatory meaning for friendship and combining it with political corruption or giving consent to it (Keles et al., 2011). Unlike the case of nepotism, the sources of the term «cronyism» can be traced back to such Greek terms as «chronios» - lasting and «chronos» - time (Barnhart, 1999). The concept of cronyism is often considered in the context of politics and favouring people in the workplace (Arasli and Tumer, 2008). Cronyism means then «giving preference to politicians, particularly to cronies, which means close friends, especially as evidenced in the appointment of hangers-on office without regard to their qualifications». With the help of the term «favouritism», these authors describe «the provision of special privilege to friends, colleagues and acquaintances, in the areas of employment, career and personnel decisions». Bearing in mind the complexity of human relationships, we find it extremely difficult to control such phenomena as favouritism or cronyism. Similarly, to nepotism, both favouritism and cronyism have a negative impact on the organization, which results from the selection of the form of employment and staff selection. 

Perspective

The concept of nepotism is not homogeneous. It covers a broad spectrum of family relationships that are connected with professional relationships. I-Pang Fu, referring to the works of Padgett and Morris (2005), talks about two forms of nepotism, i.e. «cross-generational nepotism» and "paired employees». Cross-generational nepotism refers to the employment of family members who are from the first two or older generations. This phenomenon is usually found in family businesses. The nepotism called «paired employees» raises greater controversy. The term refers to a dual career and relationship between husband and wife in the office. The controversies are associated with situations when married couples apply to work in the same workplace. In this context, some scholars, such as Padgett and Morris, contest the anti-nepotistic policy pursued in many companies. They believe that such careers can better balance work and link family responsibilities in situations when they become significant actors in the workplace (Fu, 2015). Another division of nepotism is proposed by Mary L. Williams and D. Laker, who mention four basic forms of the phenomenon. The first is «family nepotism» and means the employment of family members by the owner of a given company. It should be noted that this type of nepotism, most often assessed negatively, is usually found in family businesses (Jackiewicz et al., 2013). The second form of nepotism according to Williams and Laker is the employment of a spouse in a prominent position. In the literature on the subject, it is called «paired employees». Controversies in this respect are caused by anti-nepotistic practices, which consequently lead to the worse treatment of women than men. Lack of respect for human rights is also paid attention to in such cases. Nepotism can also be understood in a political sense, i.e. «political nepotism» - supporting a family member when hiring for a particular political position. As a consequence, we are dealing with further forms of corruption. In the fourth - last - meaning, nepotism can be understood as the employment of a relative related to an existing employee other than the owner of the company and other than the spouse. Williams and Laker call this form «organizational nepotism». Discussions on this form of nepotism concern honest human resources management and the sense of justice in the organization (Williams and Laker, 2010). We see, then, that the views of Williams and Laker converge on the issue of nepotism defined as «paired employees». In employment, nepotism most often occurs where the remuneration for work is high, the requirements are small, and the organization's results depend to a small extent on the qualifications and skills of managers. It is also fostered by the delegation of decisions to employ people below in the hierarchy and opportunities for hidden payment (Ponzo and Scoppa, 2010). The level of nepotism is also influenced by the requirements for company managers. Where the requirements are lower, the probability of choosing a manager in a nepotistic way is higher. This is due to the lower impact of the quality of the manager's work on the company's performance, and hence the smaller losses resulting from the employment of someone with low qualifications. In practice, the managing director of the family is most often employed in small companies with low R\&D expenditure and high spending on promotion and advertising. With the increase in the size of the company, and, which follows, the requirements for managers, the percentage of people not related to the family of the company's owners increases (Lin and $\mathrm{Hu}, 2007$ ). The phenomenon of nepotism in employment is also mentioned when hiring people for ordinary jobs. Also, here, as in the case of managerial positions, the phenomenon occurs more often with less demanding workplaces. Research carried out in Sweden has shown that it is popular when newcomers are entering the labour market. There was a dependence, that the less demanding and the lower paid work, the worse results were achieved by the person entering the labour market and the higher the probability of nepotism (Kramarz and Skans, 2007).

Organization's attitude to nepotism is usually negative, although a certain part of the company's environment may judge the candidate selected on the basis of family relationships neutrally or even positively. This is especially true if the family members employed are related to the owners of the family business. The widespread negative attitude towards nepotism results from the effects that it brings if it is taken into consideration when hiring staff. In most situations, employing a family member results in 

Perspective

negative consequences. Only when the choice of a person related to the family had substantive grounds, i.e. the person has the qualifications necessary to perform their functions, such a choice offers benefits, in particular, if it concerns a family business and a person related to the family of the owners (Padgett et al., 2015).

As far as the disadvantages of nepotism are concerned, the first one to be mentioned is the perception of the person employed in the organization in this way. It can be assumed that if organizations introduce best practices in the field of employment, evaluation and promotion of their own employees, nepotism can bring some benefits. It is about the organization itself and about its employees. In addition, no one should feel hurt if all candidates for a given position in an organization go through equal and fair procedures, and the person hired is the best candidate for the job, no one is harmed. This does not change the approach to nepotism itself, the impact on satisfaction and motivation of other employees, the opinion about the organization itself and the practices it uses (Riggio and Saggi, 2005). In fact, the subordinates, regardless of the competencies of the person employed, will perceive them as an inferior and less competent employee (Padgett et al., 2005). Some researchers (Padgett, Morris) say that such people are stigmatized by the environment (Padgett and Morris, 2015). This results in negative consequences for the organization. The subordinates of the person employed on the basis of family connections experience less job satisfaction, less willingness to get involved in the organization and lower motivation (Padgett and Morris, 2015; Padgett et al., 2005; Abdala et al., 1998; Ali and Ekiz, 2006; Quaisar, 2016). Nepotism can provoke jealousy and resentment among other employees (Eiving, 1965). Their trust in the organization (Keles et al., 2011) and the managerial staff are reduced (Vveinhardt and Petrauskaite, 2013). It has a negative impact on the company's organizational culture (Vveinhardt and Petrauskaite, 2013). Interpersonal communication is difficult. Persons employed on a normal basis have concerns for cooperation and communication with persons employed on the basis of family connections (Vveinhardt and Petrauskaite, 2013). Employees' willingness to leave the company also increases (Padgett et al. 2015), and also, if information about the practices of nepotism gets into the environment, the willingness to hire outsiders decreases (Eiving, 1965). At the same time, such a supervisor has less chance of getting support from his subordinates (Padgett et al., 2015). There may also be a problem with the transfer of intra-family conflicts to the organization, which, if it concerns the management staff, may translate into its malfunctioning (Vveinhardt and Petrauskaite). The large role of nepotism in recruitment processes results in less employee involvement in improving their qualifications (Ponzo and Scoppa, 2010). Research shows that as the importance of nepotism in the functioning of the organization increases, the willingness to invest in social capital decreases, as well as the willingness to improve qualifications in education processes, decreases (Perez-Alvarezy and Strulik, 2018). This negative effect is strengthened in the case of the educational processes of family members of the company's owner. Research carried out on students in Turkey showed a strong correlation between being a child of a parent running their own business and weaker results in learning, less willingness to graduate and less entrepreneurship (Gevrek and Gevrek, 2008). Only in the case of free professions, a reverse tendency was observed, in which parents who had a free profession had a positive influence on their children's learning outcomes, and also transferred skills and professional competencies (Aina and Nicoletti, 2014). As a rule, poorly assessed employment of family members does not always have to be treated so negatively, especially in family businesses. Nepotism in such companies is a natural phenomenon, morally justified by family ownership title to the company's assets (Popczyk, 2017). In the case of employing a candidate from this family in a company, you can use the previous interaction of this candidate with the family and use the mutual interdependence of family members, which is support by culture. Mutual social connections of such candidates are higher than in the case of people outside the family. Such circumstances favour the construction of a company's social capital, which can be used for 

Perspective

better knowledge management in the organization, which translates into strengthening competitive advantages (Jaskiewicz et al., 2013).

The play of interests of various social groups in the family company is important. Each employee belongs to one of these groups. Also, the interests of individual social groups do not always coincide with the interest of the organization itself. In family enterprises, a relatively stable social group is the family which, due to its specificity and position in the company (power resulting from ownership) is not forced to confront other groups, while its goals are consistent with the interest and aims of the organization itself. Therefore, it is important to hire competent and properly prepared family members, because such policy translates into an increase in the scope of family power in the organization and higher employee loyalty (Popczyk, 2017). The strong position of the family, supported by appropriate competencies of its members and relationships, allows to improve the innovation of the company thanks to greater willingness to make long-term investments supported by authoritarian decisions of owners that could be impossible for non-family enterprises, where pressure for quick return of capital and increase in value is stronger (Miller, 2015). The employment of a nepotistic candidate, if he is qualified, can also be positively evaluated by his superiors (Eiving, 1965). At the same time, if the family has a lot of control over the company, the manager from the family reduces the probability of conflicts between the owners of the company (family) and the manager of the company, which may even result in restricting the freedom of the manager. One does not also have to monitor the manager from the family so closely (Lin and $\mathrm{Hu}, 2007$ ). Leaders employed on the basis of family connections are characterized by a higher level of loyalty and involvement in the organization. When they are positively evaluated by the environment, they also manage to gain greater trust and commitment with other members of the organization. It can contribute to the formation of so-called communal organizations with a more holistic attitude of employees who will feel part of a larger whole i.e. the organization, which will result in their greater responsibility for their actions, greater involvement, loyalty, stronger relationships between employees, better integration of organizational processes and more effective solving of emerging problems (Padgett et al., 2015). When looking for positive elements in nepotism, one can refer to genetics. People inherit their genes from their parents. If these turned out to be efficient managers who developed their family business, then one of the factors determining success could be predispositions resulting from character traits and the organism. Children of such people inherit some of these traits, i.e. they may be genetically predisposed to perform similar functions. At the same time, the genetic factor can be strengthened by the family environment in which the person grows up and in which from the beginning of his life he is accustomed to the future role of the manager in the parents' company (Jones and Stout, 2015).

When writing about nepotism, one must take into account cultural differences and the resulting different approach to this phenomenon. In countries characterized by a collectivist culture, aimed at supporting family members (e.g. Asian countries), nepotism is accepted and widely used as a practice of employment. If it is not practised, conflicts may arise. It is normal in China (Chen et al., 2013; Luo et al., 2012). In the Arab world, family ties are a typical way to bypass formal procedures (Williams and Bezeredi, 2017). And there is no trust in people employed in managerial positions outside the family. This is due to the Arab culture in which loyalty and dependence on the family have been instilled since childhood. This translates into the behaviour of managers raised in such culture, who are instilled in putting the interest of the family above their own and paying off a kind of debt to it in a loyal service for the company (Sidani and Thornberry, 2013). As a result, nepotism is not evaluated negatively (Nadeema et al., 2015). This does not mean that it has no negative effects on the development of the company and its future. Let us add that societies in countries with individualist culture (Western Europe, USA, etc.) nepotism criticize and take action to limit it. Differences in the approach to nepotism may also occur in countries from a similar cultural background. They will not be large, but they are noticeable. Colin C Williams together with local researchers carried out a study related to nepotism and so-called the 
«vruzki», «vrski» and «blat» phenomena that are used to describe bribery in the countries of Central and Eastern Europe (Macedonia, Bulgaria, Ukraine). The results were similar in all these countries, although noticeable differences were identified. In Macedonia, the «vrski» when looking for a job was used by young people, with higher incomes, living in small towns and in the countryside (Williams and Bezeredi, 2017). In Bulgaria, «vruzki» was also more often used by young people with higher incomes, but unlike in Macedonia, more often by residents of large cities (Williams and Yang, 2017). In Ukraine, similar practices are used much more frequently than in Bulgaria or Macedonia to gain access to educational services (Williams and Onoshchenko). In other words, such practices are more common.

It should be noted that in order to prevent problems that may be generated by nepotism, antinepotistic policies are implemented in many organizations. However, it may turn out that the introduced rules, which were to protect the organization from employing incompetent persons, generate some problems themselves. Specifically, they do not allow to hire people with the highest qualifications for the sole reason that they are related or married to people already working in the organization. In addition, it may happen that qualified employees who are employed on the basis of high competences, meet at work, fall in love and decide to marry. The anti-nepotistic policy, that is strictly observed in the organization, may lead to one of the employees having to leave to a different location of the company, if it exists, or leave the organization (Fisher, 2005). It is worth considering in this context whether the phenomenon of nepotism should be approached in such a severe manner.

The issue of nepotism should be considered in the context of its importance to social capital. Generally speaking, the success of an enterprise is not only dependent on the condition of financial and material resources and human capital, but also on the value of social capital which during last three decades became one of the most influential concepts serving the explanation of social behaviour on different levels (Lin, 2017). The very term «social capital» appears in the United States in 1916 in the discussion of the possibilities of cooperation between neighbours when supervising a school. In this context, Lynda Hanifan spoke about social capital as «tangible assets, which count most in everyday lives of the people: goodwill, comradeship, sympathy and social interaction among individuals and families forming a social unit» (Keeley, 2007). In the mid-1960s, Canadian sociologists, such as John Roland Seely, Alexander Sim and Elisabeth Loosely, used the term social capital to discuss the culture of urban society. In the 1970s, social capital has become the subject of economists' studies. Today it is used by sociologists, economists and political scientists (Eroglu and Kangal, 2016).

At the same time, it should be noted that not long ago the concept did not exist in English dictionaries at all (Partrige, 1991; Crowther, 2006). It is therefore understandable that the term «social capital» is far from clarity. There is also mentioning that the concept of «social capital» is more than two million references, close to «human capital» (2180000), comparing to less popular «cultural capital» 467,000 and «relationship capital» only 7050 (Scholar, 2018). There are also authors claiming that the concept of social capital is burnt. It is worth mentioning that the phrase «social capital» has more than two million references, close to «human capital» (2180000), comparing to less popular «cultural capital» - 467000 and «relationship capital» only 7050 (Scholar, 2018).

Among different ways of defining social capital the most popular are close connections with «social trust», «cultural capital», «human capital» or «relationship capital». We need to remember that there are many ways to understand the relations with trust, cultural capital and relationship capital. A brief look at different classical definitions of social capital proves how differentiated the phenomenon is. Bourdieu (1983) defines social capital as «the aggregate of the actual or potential resources which are linked to possession of a durable network of more or less institutionalized relationships of mutual acquaintance and recognition». Coleman (1988) defined social capital functionally as «a variety of entities with two elements in common: they all consist of some aspect of social structure, and they facilitate certain actions of actors». Putnam (2000) perceives social capital as «connections among individuals and social 

Perspective

networks and the norms of reciprocity and trustworthiness that arise from them». Fukuyama sees social capital as generally understood rules that enable people to cooperate such as the norm of reciprocity (Sulkowski, 2017). The notion of social capital got into the discourse of management science thanks to the proximity to the economy, organizational sciences, and managerial practices (Cohen and Prusak, 2001; Chmielecki and Sulkowski, 2018). The concept has become more and more popular in business and management during the last 20 years (Ferragina and Arrigoni, 2017; Adler and Kwon, 2002). Social capital determines the actual resources, the existence of which is of social significance. There is a number of features of the characteristics of social capital starting with production where social capital is created with the use of specific material resources, financial resources, work, and time. Another element of the characteristics is transformation, here social capital has the ability to transform certain goods (material resources, financial resources, work, and time) into benefits that cannot be obtained in a different way (e.g. the use of someone else's knowledge, skills, ensuring privileged treatment, receiving emotional support or support in a difficult situation etc.) (Woolcock and Narayan, 2000). During the investment process material resources, financial resources, work, and time are invested in the creation of an atmosphere favouring mutual trust. Stronger ties require larger investments, while weaker ties require smaller investments. Similar to material capital, social capital is of heterogeneous nature (diversity) (Reagans and Zuckerman, 2001). Social capital is also characterized by predictability and different degrees of stability. Social capital needs to be attended to - in order to maintain its productivity, it needs to be «used» from time to time. The creation and maintenance of social capital are preceded by the calculation of cost and benefits, which is called «alternative cost». The final characteristics are transferability which is only present in social capital only partially as it is impossible to resell or hire social capital. Social capital can be transferred or inherited in a certain way (e.g. parents' friends become also children's friends) (Inkpen and Tsang, 2005).

In business and management the concept of «social capital» is frequently used in connection with issues like organizational culture (Nahapiet and Sumantra, 2000) and identity (Whetten, 2006; Brickson, 2007), corporate social responsibility (Jones et al., 2001), human resources management (Botelho, 2017), marketing and e-commerce (Mutz, 2005), social networks (Chen et al., 2017) and finance (Aggarwal et al., 2015). In the concept of social capital draws attention to the equally significant role of the family in building and supplying this component in the workings of the economy and society (Bubolz, 2001). For the needs of this paper, we can use the definitions dominant in the literature, treating social capital as social trust, connections and social networks that facilitate cooperation and reciprocity. Referring to nepotism, the phenomenon occurs in a wider scope where social capital is smaller. Despite the number of its definitions and the difficulties associated with its measurement, it is certain that the value of social capital is based on mutual social relations and trust that exists between individuals. Thus, nepotistic practices affect the reduction of social capital because they weaken its pillars, that is are the trust and social relations in the organization.

In addition, nepotism significantly worsens the social capital of the organization, because it is also an element decreasing social capital, in this way the reduced social capital promotes nepotism. As a result, the organization «infected» with nepotism is exposed to the risk of a vicious circle resulting in a permanent reduction in the level of social capital, which leads to its deterioration. Therefore, it is so important to learn and effectively counteract the nepotism in the organization if it has a negative form for the organization.

Results. The main goal of the research was to analyse the phenomenon of nepotism in Poland and Ukraine. The research also covered the phenomenon of cronyism, which in the literature is usually considered in the context of nepotism. In particular, an attempt was made to determine the scale of the phenomena of nepotism and cronyism in Poland and Ukraine, to assess the impact of these phenomena on the functioning of entities and opinions on the topic of nepotism and cronyism in Polish and Ukrainian 
society. On the basis of the above goal, the following research hypotheses were formulated. The first four of them relate to the scale of nepotism and cronyism. Based on previous studies (Sroka and Vveinhardt, 2018; Onoshchenko and Williams, 2014; Williams and Onoshchenko, 2014) and depending on the scale of its occurrence from the geographical region, the authors assumed that:

$\mathrm{H} 1$ : Nepotism is a common phenomenon in Poland

$\mathrm{H} 2$ : Nepotism is a common phenomenon in Ukraine

H3: Nepotism is a noticeably more common phenomenon in Ukraine than in Poland.

In addition, the literature analysis indicates that the larger the enterprise, the smaller the scale of nepotism and cronyism, so these phenomena are least common in corporations, they are much more common in small ones, especially in family businesses. As nepotism is often associated in the literature with cronyism, and some studies combine both phenomena to a certain extent, it was decided to compare the phenomenon of nepotism with cronyism (Williams and Bezeredi, 2017; Williams and Yang, 2017; Ponzo and Scoppa, 2010). This is due to the fact that there are significant differences between these phenomena, although their effect on the functioning of the company is similar. The authors decided to spot these differences hence the following research hypothesis was made:

$\mathrm{H} 4$ : Cronyism is a more common phenomenon than nepotism.

The next hypotheses refer to the influence of nepotism and cronyism on the functioning of entities in Poland and Ukraine. The authors assume that the impact is almost always negative, and in certain specific circumstances it can also be positive. Such situations have been described in the literature (Jaskiewicz et. al., 2013; Popczyk, 2017; Miller et. al., 2015; Eiving, 1965; Lin and Hu, 2007; Padgett et al. 2015). There may also be dual situations when nepotism affects the organization both positively and negatively. Therefore, the following research hypotheses were proposed:

H5: Nepotism has a negative impact on satisfaction, motivation to work, commitment, trust in the organization, willingness to work in the organization.

H6: Cronyism has a negative impact on satisfaction, motivation to work, commitment, trust in the organization, willingness to work in the organization.

$\mathrm{H} 7$ : Nepotism, with the proper competence of the manager, has a positive impact on employee commitment, satisfaction, motivation to work,

Finally, the authors decided to define opinions on nepotism and cronyism. Based on the available literature (Sroka and Vveinhardt, 2018; Onoshchenko and Williams, 2014; Williams and Onoshchenko, 2014; Padgett and Morris, 2005; Padgett et al., 2015; Hagen et al., 1998), in which the vast majority of both nepotism and cronyism were evaluated negatively, the following research hypotheses were put forward:

H8: Nepotism is negatively assessed by employees in Poland and Ukraine

$\mathrm{H}$ : Cronyism is negatively assessed by employees in Poland and Ukraine

$\mathrm{H} 10$ : The assessment of nepotism is more lenient in Ukraine than in Poland

$\mathrm{H11}$ : The assessment of cronyism is more lenient in Ukraine than in Poland

Verification of the above research hypotheses was carried out on the basis of the results of a quantitative study. The conclusions from the research conducted on a statistical representative sample refer to the general population formulated as working part-time students of private universities in Poland. The study was conducted from February to May 2019. Most of the students that took part in the study already work, so they have the experience necessary to answer the questions of the survey. A similar attempt was made by Padgett, Padgett and Morris in their research (Padgett et al., 2014, Padgett and Morris, 2005). The research was carried out in both large and smaller didactic centres, attended by a total of 691 respondents, of whom:

- $61.0 \%$ were women;

- $61.2 \%$ were people under 30 years of age; 

Perspective

- $59.6 \%$ were people with secondary education, $11.6 \%$ people with post-secondary education, and $26.7 \%$ with higher education;

- almost $72.7 \%$ were Poles, almost $26.8 \%$ Ukrainians, and less than $0.5 \%$ students of other nationalities, with $78.0 \%$ of foreigners participating in the study living in Poland for no more than 5 years;

- $38.4 \%$ of respondents are business owners or people working in private enterprises, $23.8 \%$ are employees of state or business administration, $17.0 \%$ are corporate employees, $4.8 \%$ have casual jobs, and the remaining $16 \%$ are non-working people;

- the largest number of working people is employed in large enterprises $-32.7 \%, 23.3 \%$ in medium-sized enterprises, $22.4 \%$ in small enterprises and $21.6 \%$ in micro-enterprises.

The structure indicators provided were calculated on the basis of valid responses, whereas the no answer rate for the majority of questions was no more than 3.3\% (only in the case of the question about gender the share of non-valid answers was $11.6 \%$ ). Statistical methods, including methods of statistical inference, were used to verify the research hypotheses. The variable analysis, such as the scale and assessment of nepotism or the scale of cronyism, have a multidimensional character, moreover, they are qualitative or quasi-qualitative variables. Therefore, their operationalization is based on simultaneous consideration of the answers to a number of questions in the survey using synthetic statistical measures, i.e. how to mean scales - averages from answers on a given scale given to questions about a given phenomenon («Due to the fact that all variables included in a given synthetic measure assume values from the same intervals, there was no need to use more complex measurement methods, such as Hellwig's multidimensional development measure» (Stec, 2009)). For example, the scale of nepotism is determined on the basis of the average of answers provided by the respondents' answers to the question of to the frequency of occurrence such as employment of a relative of the owner of the business, person responsible for recruitment or someone in the company, promoting relatives, paying higher wages to a relative, better treatment or a more lenient assessment of a relative. The answers taken into account were on the 0-4 scale, where 0 means that such a phenomenon never occurred, 1 sporadically, 2 - rarely, 3 - often, 4 - very often (originally, the scale used was a five-level 1-5, where 1 - never). Thus, the synthetic measure of the scale of nepotism in the opinion of the respondent may take values from the range of $0-4$, where 0 would mean that the subject never met with any of the symptoms of nepotism mentioned in the survey, and 4 that he often meets all the mentioned manifestations of nepotism. An analogous method was used to measure the scale of cronyism and to assess the phenomenon of nepotism and cronyism. In the case of verification of hypotheses concerning the comparison of the nepotism scale in Poland and Ukraine $(\mathrm{H} 3)$, the comparison of the scale and the assessment of nepotism and cronyism $(\mathrm{H} 4, \mathrm{H} 10, \mathrm{H} 11)$ parametric tests for mean values (based on the mean averages) were used. In addition, in order to verify hypotheses about the scale of nepotism and cronyism, the non-parametric dependency tests (Spearman rho) and non-parametric median tests and one-factor analysis of Kruskal-Wallis variance in the study of the dependence of the nepotism scale on the type of subject (respondent's place of work) were performed. In the case of the first hypothesis, which was:

$\mathrm{H} 1$ : Nepotism is a common phenomenon in Poland

The assessment of the scale of nepotism was based on the fact that the respondents defined how often they encountered situations that could indicate the occurrence of this phenomenon. Only $15.3 \%$ of Poles surveyed never encountered a situation of employment of a relative related to the owner of the company or a manager responsible for recruitment for a managerial position, while $40.2 \%$ of those asked met frequently or very often with such a situation. On the other hand, only $12.4 \%$ of the Polish students interviewed never encountered a situation of employment of a person related to the owner of the company or a manager responsible for recruitment for a regular position, while $44.9 \%$ of those asked met this situation often or very often. The percentage of respondents who never met with the other 
nepotism symptoms mentioned in the survey did not exceed $1 \%$, they met particularly often a better treatment or a more lenient assessment of a relative related to the owner or superior of that person (see Figure 1). These indicators allow claiming that from the perspective of part-time students of private Polish universities nepotism is a common phenomenon in Poland (positive verification of the $\mathrm{H} 1$ hypothesis).

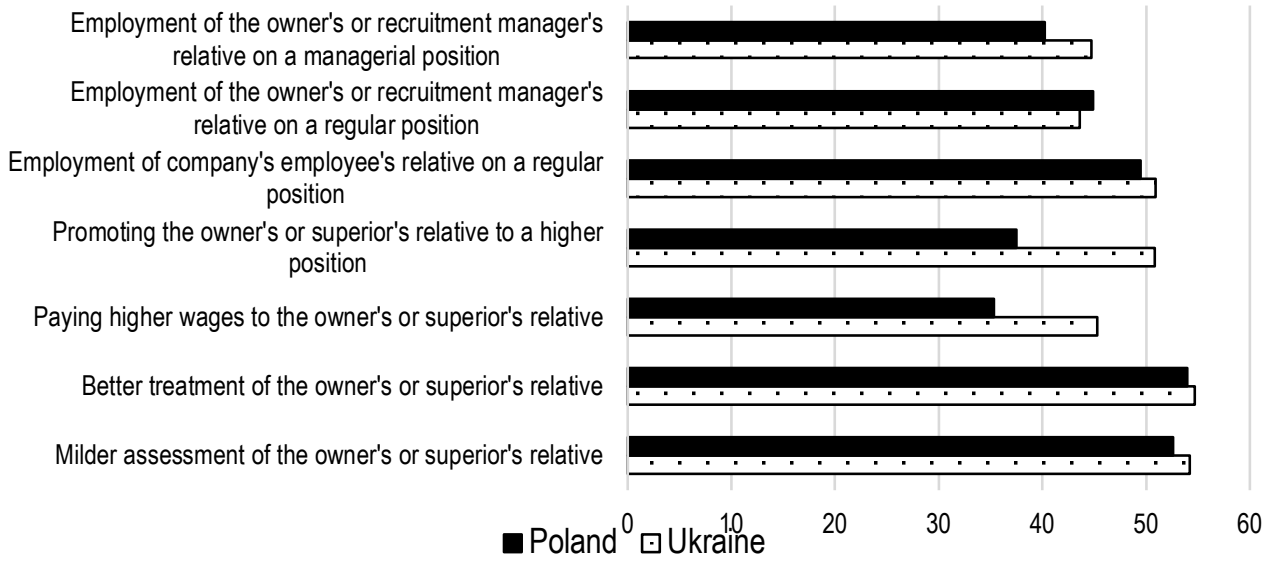

Figure 1. Percentage of respondents from Poland and Ukraine, who met with nepotism often or

Source: developed by the authors. very often

In the case of the second hypothesis, which was:

$\mathrm{H} 2$ : Nepotism is a common phenomenon in Ukraine

More than half of the Ukrainian students surveyed often or very often met with the symptoms of nepotism in the form of employment of people related to someone in the company, promoting, better treatment or a milder assessment of relatives. The share of people who never met with the symptoms of nepotism listed in the survey exceeded $10 \%$ only in the case of recruitment of a person related to the business owner or a manager responsible for recruitment (11.2\%). This allows for positive verification of the hypothesis that nepotism is a common phenomenon in Ukraine. In order to compare the scale of the phenomenon of nepotism in various types of organizations and enterprises of various sizes, a synthetic meter was constructed which is the average of values on the scale 0-4 (a description of the method of calculating the meter was presented earlier). These meters themselves do not have an interpretation but allow comparative analysis (see Figure 2.)

The nonparametric correlation test for the Spearman's correlation indicator shows that the relationship between the nepotism scale and the size of the company is statistically insignificant (the Spearman coefficient based on the sample of 576 workings is equal to 0.022 , the p-value is 0.606 ). In turn, the comparison of the scale means in sub-samples distinguished by the type of organization as a workplace indicates statistically significant differences in the scale of nepotism ( $p$-value equal to 0.023 in the Kruskal-Wallis test for 3 independent samples).

The scale of nepotism is significantly higher in state institutions than in private enterprises ( $p$-value equal to 0.049 in the significance test for average values) and corporations ( $p$-value 0.003 ), while the scale of nepotism is significantly lower in corporations than in private enterprises ( $p$-value 0.053). In the case of the third hypothesis which was:

H3: Nepotism is a noticeably more common phenomenon in Ukraine than in Poland. 


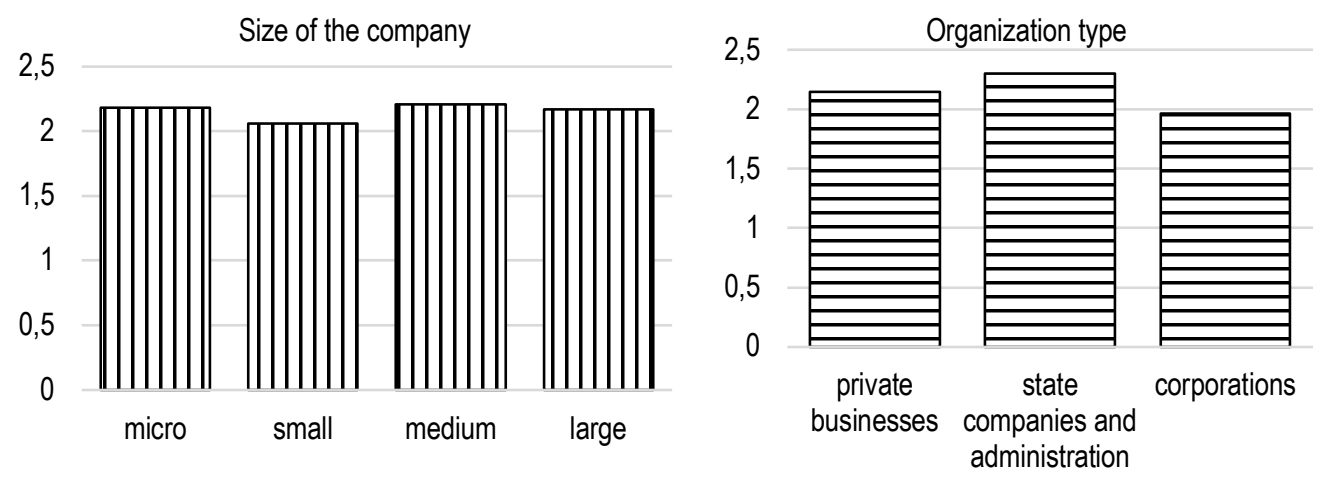

Figure 2. The scale of nepotism by company size and organization type Source: developed by the authors.

In order to compare the frequency of occurrence of nepotism in Poland and Ukraine, tests of equality of structure indices were carried out. The share of the surveyed Ukrainians, who often or very often met in promotion of relatives or paying a higher salary to a person related to the owner or superior of this person was significantly higher than the corresponding share of surveyed Polish students (at the level of significance 0.001 ). In addition, in order to compare the scale of the phenomenon of nepotism in Poland and Ukraine, a synthetic measure was constructed which is the average of values on a scale of 0-4 (a description of the method of calculating the meter was presented earlier). The test of equality of average scale values in two independent samples (distinguished on the basis of nationality: the sample of Poles and Ukrainians) indicates that the scale of nepotism in Ukraine is significantly higher than in Poland at the level of significance 0.05 (see Table 1).

Table 1. Equality test of mean scale values defining the scale of nepotism

\begin{tabular}{|l|c|c|c|c|c|}
\hline Nationality & $\begin{array}{c}\text { Number of } \\
\text { samples }\end{array}$ & Mean & $\begin{array}{c}\text { Standard } \\
\text { deviation }\end{array}$ & $\mathbf{t}$ & $\begin{array}{c}\text { p-value } \\
\text { (one-tailed) }\end{array}$ \\
\hline Poles & 485 & 2.1193 & 0.96005 & -2.15 & 0.016 \\
\hline Ukrainians & 179 & 2.2993 & 0.94878 & & \\
\hline
\end{tabular}

Source: developed by the authors.

The conclusions from the above test (and the Kruskal-Wallis test) allow for positive verification of the hypothesis that from the perspective of private universities' students' nepotism in Ukraine is noticeably more common than in Poland. The next phenomenon subjected to the study was cronyism. The universality of the phenomenon of cronyism is indicated, among others, by over $40 \%$ of respondents who often or very often met with the employment for a managerial or regular position, better treatment or milder assessment of the owner's or recruitment manager's friend. In turn, the percentage of students who have met with the symptoms of nepotism mentioned in the survey is relatively small (see Figure 3). 
G. Ignatowski, B. Stopczynski, J. Trebska. Paradox of Nepotism in Enterprises in Poland and Ukraine: Social Capital Perspective

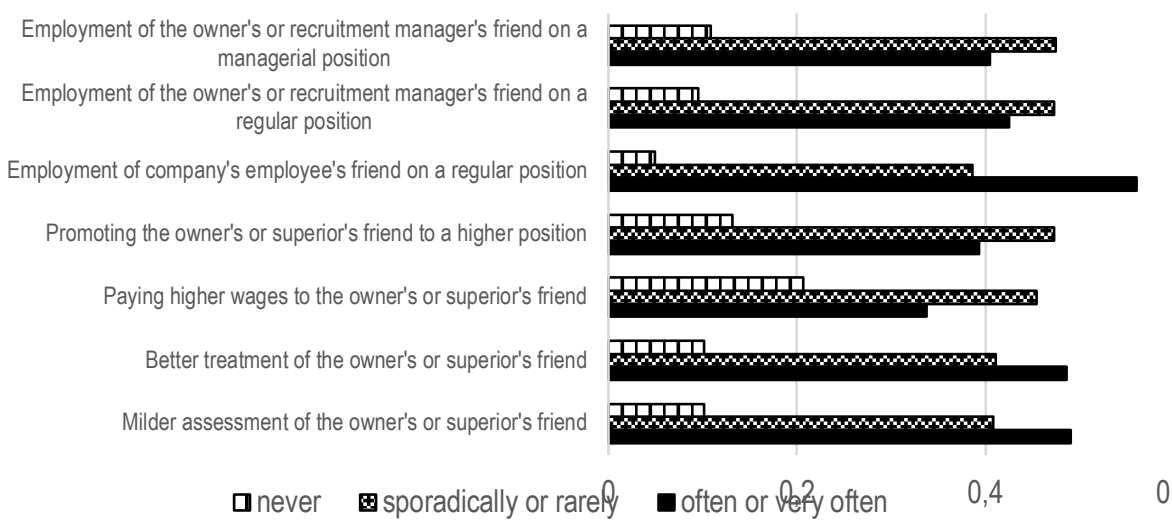

Figure 3. Structure of the respondents from the point of view of the observed scale of cronyism Source: developed by the authors.

The next was the fourth hypothesis, which was:

H4: Cronyism is a more common phenomenon than nepotism.

In order to compare the scale of nepotism and cronyism, synthetic measures of nepotism and cronyism were determined (according to the method described earlier). The values of the measures do not have an interpretation. However, they allow to compare the scale of these phenomena thanks to the fact that answers to questions regarding manifestations of both phenomena were given on the same scale (0-4). The equality test of average scale values for dependent samples indicates that these averages do not differ in a statistically significant way (on the basis of a sample of all Poles and Ukrainians surveyed), and therefore, in the light of the conducted research, it cannot be said that the phenomenon is more common than nepotism (see Table 2). At the same time, from the perspective of part-time students, the scale of nepotism in Poland is significantly greater than the scale of the cronyism, while in Ukraine it does not differ significantly.

Table 2. Equality test of average scale values determining the scale of nepotism and cronyism

\begin{tabular}{|l|l|c|c|c|c|}
\hline \multicolumn{1}{|c|}{ Dependent samples } & Phenomenon & Mean & $\begin{array}{c}\text { Standard } \\
\text { deviation }\end{array}$ & $\mathbf{t}$ & $\begin{array}{c}\text { p-value } \\
\text { (two-tailed) }\end{array}$ \\
\hline $\begin{array}{l}\text { Poles and Ukrainians } \\
\text { together) } \\
\mathrm{N}=664\end{array}$ & Nepotism scale & 2.1678 & 0.95964 & 1.608 & 0.108 \\
\cline { 2 - 5 } $\begin{array}{l}\text { Poles } \\
\mathrm{N}=485\end{array}$ & Cronyism scale & 2.1433 & 0.92509 & & \\
\hline $\begin{array}{l}\text { Ukrainians } \\
\mathrm{N}=179\end{array}$ & Nepotism scale & 2.1193 & 0.96005 & 1.841 & 0.066 \\
\cline { 2 - 4 } & Cronyism scale & 2.0878 & 0.91461 & & \\
\cline { 2 - 6 } & Nepotism scale & 2.2993 & 0.94878 & 0.172 & 0.863 \\
\hline
\end{tabular}

Source: developed by the authors.

Subsequently verified hypotheses assessed the influence of nepotism and cronyism on the attitudes of employees in the organization. The fifth hypothesis assessing the influence of nepotism was $\mathrm{H} 5$ : Nepotism has a negative impact on satisfaction, motivation to work, commitment, trust in the organization, willingness to work in the organization. The sixth hypothesis concerned cronyism and was H6: Cronyism has a negative impact on satisfaction, motivation to work, commitment, trust in the organization, willingness to work in the organization. 
In the opinion of the respondents, nepotism has a negative impact on job satisfaction in the organization (enterprise, institution, etc.), motivation to work, commitment, trust in the organization or even willingness to work in the organization in which there is a phenomenon of nepotism consisting in employment due to kinship. This opinion was expressed by the vast majority of the respondents (see Figure 4). Significance tests indicate that the influence of nepotism on listed aspects of the organization's functioning is actually assessed negatively (at the level of significance 0.001 the negative rating rate is greater than $50 \%$ ). The assessment of the impact of cronyism on the functioning of the organization is similar, which is confirmed by relevant significance tests for structure indicators (at the level of significance 0.001 the percentage negatively assessing the impact of cronyism on various aspects of the organization is greater than $50 \%$ ). Therefore, the fifth and sixth hypotheses were verified positively.

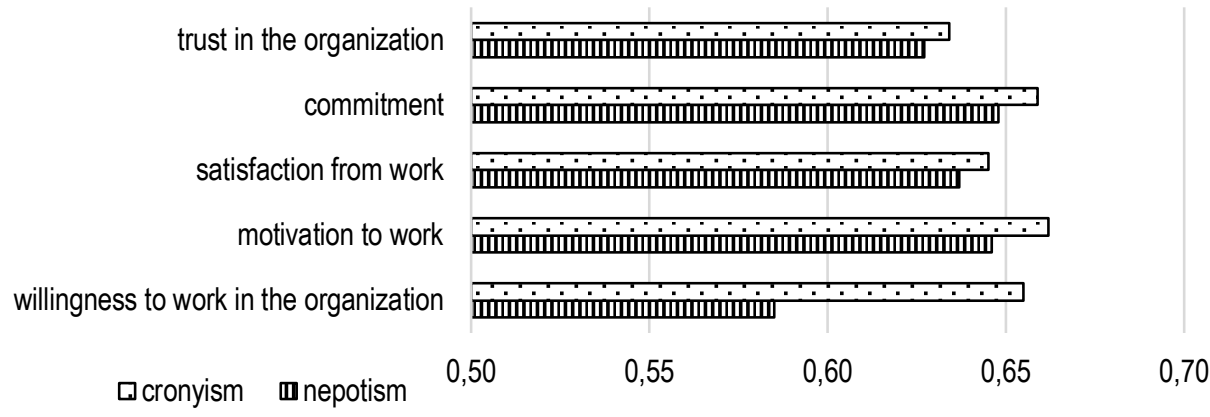

Figure 4. Percentage negatively assessing the impact of nepotism and cronyism on the functioning of the organization

Source: developed by the authors.

On the other hand, the respondents confirm that nepotism, meeting the requirement of appropriate managerial skills, can have a positive impact on employees' commitment, job satisfaction, motivation to work, as well as reducing the risk of conflicts with the owners of the company (see Figure 5). It may be favoured by the loyalty of managers, sharing knowledge between managers, and the involvement of managers in the company. Significance tests indicate that the fact of employment of a relative on a managerial position can be assessed positively if the manager's proper competence is met (at the level of 0.001 the negative assessment rate is greater than $50 \%$ ).

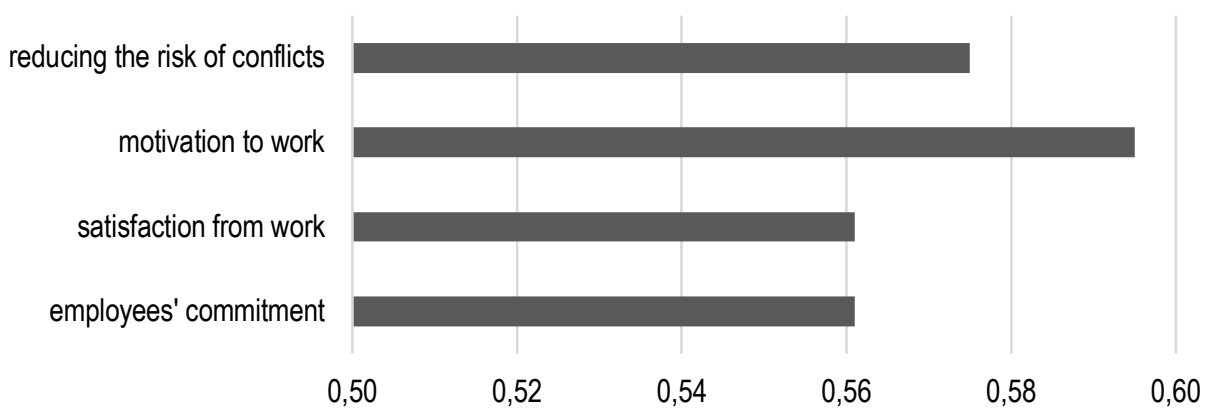

Figure 5. Percentage assessing the impact of nepotism on the functioning of the organization

Source: developed by the authors. positively (conditionally) 

Perspective

Thus, the seventh hypothesis, which was

$\mathrm{H} 7$ : Nepotism, with the proper competence of the manager, has a positive impact on employee commitment, satisfaction, motivation to work was confirmed.

In the next part of the study, an attempt was made to assess nepotism by Polish and Ukrainian working students. The majority of Poles surveyed assesses paying to related persons higher salary $(81.3 \%$ of respondents), better treatment $(78.0 \%)$, milder assessment $(76.5 \%)$, promotion of relatives $(73.0 \%)$, employing people related to a managerial position $(70.5 \%)$ as an unacceptable or inappropriate situation. The respondents assessed manifestations of nepotism in the form of hiring relatives on regular positions (38.0\% considered this situation as unacceptable or inappropriate) or assistance in employment directed to a person who is a relative of another employee of the company $(28.6 \%)$ relatively milder. These results indicate that nepotism is negatively assessed by working students in Poland (see Figure 6).

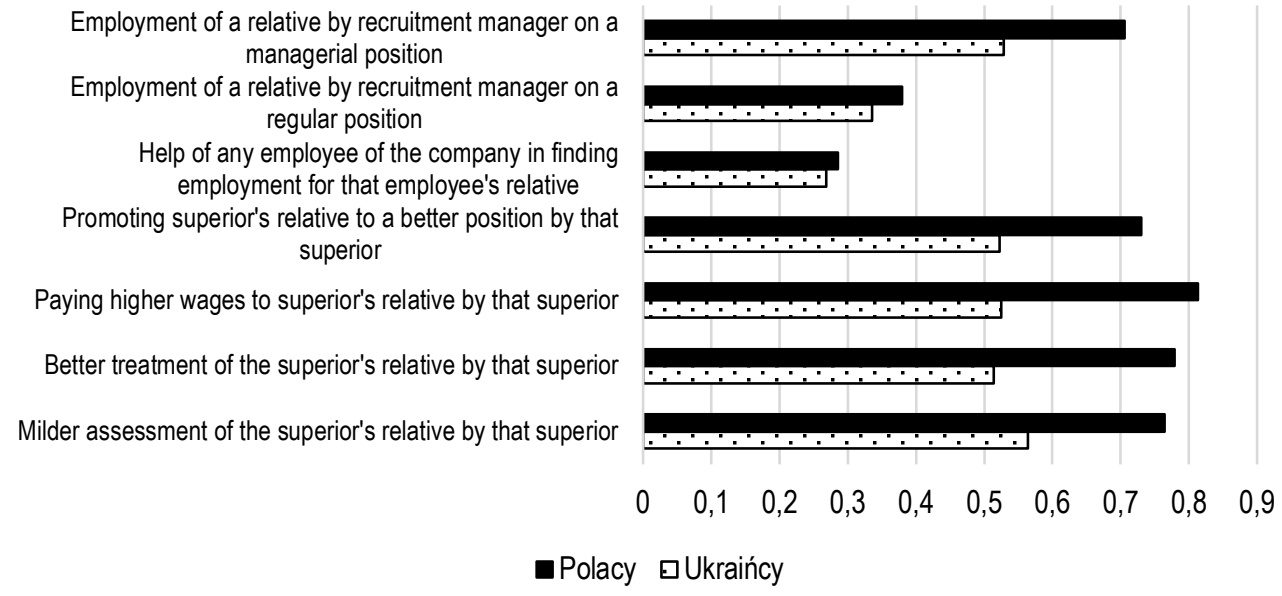

Figure 6. The percentage of respondents who perceive these symptoms of nepotism as unacceptable or inappropriate situations

Source: developed by the authors.

More than a half of the surveyed Ukrainians negatively assess manifestations of nepotism associated with a milder assessment of relatives (56.4\%) employing relatives on managerial positions (52.8\% of respondents), paying higher wages to relatives $(52.5 \%)$, promoting relatives $(52.2 \%)$, their better treatment $(51.4 \%)$. As in the case of the Poles, the employment of relatives on a regular position $(33.5 \%)$ or assistance in employment directed to a relative of another employee of a company is assessed more lightly $(26.8 \%)$. These results indicate that nepotism is rather negatively assessed by Ukrainian students (see Figure 7). The eighth and ninth hypotheses were therefore confirmed:

H8: Nepotism is negatively assessed by employees in Poland and Ukraine

H9: Cronyism is negatively assessed by employees in Poland and Ukraine

Figure 7 clearly shows that the negative assessment of the symptoms of nepotism is the characteristics of a larger percentage of Poles surveyed than Ukrainians (significance tests for structure indicators indicate that these differences are statistically significant). In addition, synthetic measures for assessing nepotism were determined based on responses provided by respondents on a scale of 1-5, where 1 means that a given situation, which is a manifestation of nepotism is assessed as unacceptable, 
G. Ignatowski, B. Stopczynski, J. Trebska. Paradox of Nepotism in Enterprises in Poland and Ukraine: Social Capital Perspective

2 - inappropriate, 3 - neutral, 4 - correct, 5 - desirable. The distribution of values that have been determined as an average of scale values is shown in Figure 7.
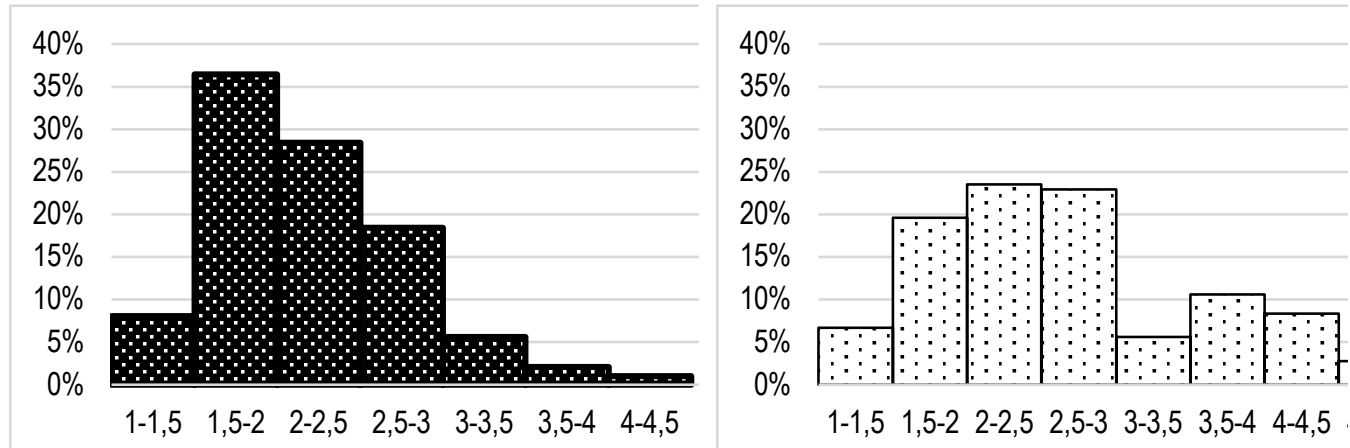

Figure 7. A synthetic measure of the assessment of nepotism among Poles (left) and

Source: developed by the authors. Ukrainians (right)

The above figure clearly shows that for the majority of respondents, both from Poland $(91 \%)$ and Ukraine $(73 \%)$ the average assessment of nepotism does not exceed the value of 3 (meaning neutral assessment). The significance test for mean values in independent samples shows that the average of scale values is significantly lower in the case of Polish students, which means that the assessment of nepotism is more lenient in Ukraine than in Poland, with the ratings of Ukrainians being much more diverse (see Table 3)

Table 3. Equality test of average mean values determining the assessment of nepotism

\begin{tabular}{|l|c|c|c|c|c|}
\hline Nationality & $\begin{array}{c}\text { Number of } \\
\text { samples }\end{array}$ & Mean & $\begin{array}{c}\text { Standard } \\
\text { deviation }\end{array}$ & $\mathbf{t}$ & $\begin{array}{c}\text { p-value } \\
\text { (one-tailed) }\end{array}$ \\
\hline Poles & 485 & 2.2197 & 0.59961 & -6.842 & $<0.001$ \\
\hline Ukrainians & 179 & 2.7127 & 0.89253 & & \\
\hline
\end{tabular}

Source: developed by the authors.

The analysis of assessments of the situations being the manifestations of cronyism provides similar conclusions. Most of the respondents negatively evaluate the practices indicating favouring superiors' friends (direct or indirect), while the respondents indicated that paying a higher salary $(79.4 \%$ of surveyed Poles and $51.4 \%$ of Ukrainians), better treatment (78, respectively, $1 \%$ and $52.0 \%$ ), favouring in promotions $(74.5 \%, 52.2 \%)$, milder assessment $(73.5 \%, 53.4 \%)$, and assistance in employing a friend is the least often assessed negatively (see Fig. 8).

In analogy to the synthetic assessment of nepotism, synthetic measures of assessing the cronyism among the surveyed Poles and Ukrainians were determined. The scaled average of assessments of situations being a symptom of cronyism does not exceed 3 in the case of the vast majority of Poles $(91 \%)$ and Ukrainians (92\%) (the distributions of synthetic measures of assessment of cronyism are very similar to the distributions of nepotism measures, therefore it was decided not to include relevant figures). 
G. Ignatowski, B. Stopczynski, J. Trebska. Paradox of Nepotism in Enterprises in Poland and Ukraine: Social Capital Perspective

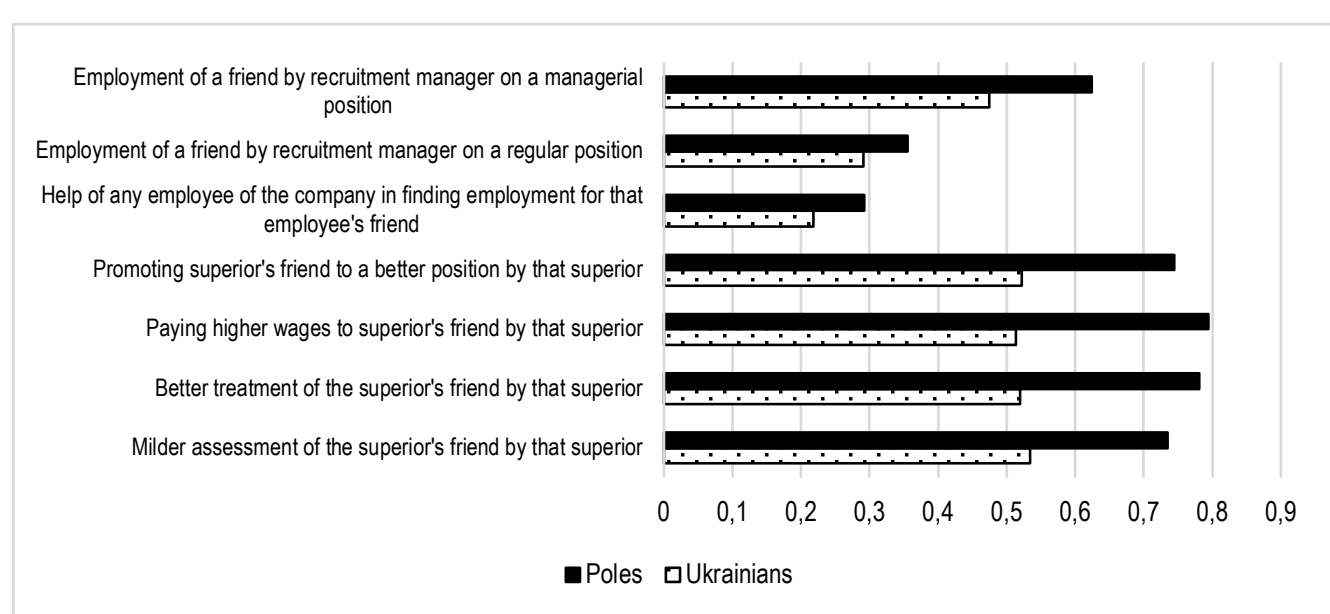

Figure 8. The percentage of respondents who described the symptoms of cronyism as unacceptable or inappropriate situations

Source: developed by the authors.

The assessment of cronyism by the Ukrainians is significantly milder than among Poles (see the results of the statistical test presented in Table 4).

Table 4. Equality test of mean scale values defining the assessment of cronyism

\begin{tabular}{|l|c|c|c|c|c|}
\hline Nationality & $\begin{array}{c}\text { Number of } \\
\text { samples }\end{array}$ & Mean & $\begin{array}{c}\text { Standard } \\
\text { deviation }\end{array}$ & $\mathbf{t}$ & $\begin{array}{c}\text { p-value } \\
\text { (one-tailed) }\end{array}$ \\
\hline Poles & 485 & 2.2698 & 0.60997 & -7.754 & $<0,001$ \\
\hline Ukrainians & 179 & 2.8300 & 0.89276 & & \\
\hline
\end{tabular}

Source: developed by the authors.

Conclusions. The hypotheses that from the perspective of working students of Polish private universities nepotism is common in both Poland and Ukraine to have been positively verified, with nepotism being noticeably more widespread in Ukraine than in Poland. The research shows clearly that the phenomenon of nepotism is the least common in corporations that are the workplace of part-time students. However, it is difficult to show that the bigger the company, the smaller the scale of nepotism. The research did not confirm that cronyism is more common than nepotism. In the opinion of the respondents, both nepotism and cronyism have a negative impact on satisfaction, motivation to work, commitment, trust in the organization, and willingness to work in the organization. When the manager's proper competencies are met, nepotism can have an advantageous impact on the functioning of the organization. Situations which are manifestations of nepotism and cronyism are most often assessed as unacceptable or inappropriate, while the assessment of these phenomena is more lenient in Ukraine than in Poland. The universality of nepotism in both Poland and Ukraine has a negative impact on the social capital of the organization and is a significant problem. Actions should, therefore, be taken to fight it. It should be remembered, however, that under certain conditions nepotism can have a positive effect on the organization. Employee assessments show that in some situation's nepotism can be perceived positively, therefore it should be remembered, introducing anti-nepotistic solutions, that they should not be used in situations in which nepotism is a desirable phenomenon. As a summary, let us remind that social capital is one of the essential components significant for the development of the company. Its level 
is influenced by such factors as positive relations with other members of a given community or the level of trust. At the same time it should be noted that we can talk about three dimensions of these social bonds in the context of social capital, namely, strong family ties called bonding social capital, weak ties connecting friends and acquaintances referred to as bridging social capital and more formal bonds called linking social capital in the professional literature. Only linking social capital exerts a positive influence on such outcomes (Sabatini, 2007). Therefore, it should be remembered that all activities and initiatives aimed at avoiding favouring people in the workplace lead to the strengthening of linking social capital as a consequence.

\section{References}

Abdalla H. F., Maghrabi, A. S. and Raggad B. G. (1998), «Assessing the perceptions of human resource managers toward nepotism. A cross-cultural study», International Journal of Manpower, Vol. 19 No. 8, p. 554-570.

Adler, P. S. and Kwon, S. (2002), «Social capital: Prospects for a new concept», Academy of Management Review, Vol. 27 No 1, pp. 17-40.

Aggarwal, R., Goodell, J. W. and Selleck L. J. (2015), «Lending to women in microfinance: Role of social trust». International Business Review, Vol. 24 No 1, pp. 55-65.

Aina, C., \& Nicoletti, Ch. (2014). «The intergenerational transmission of liberal professions: nepotism versus abilities». Discussion Papers, 14/14, Department of Economics, University of York.

Ali, H. A. and Ekiz, E. (2006), «The effects of nepotism on human resource management: The case of three, four and five star hotels in Northern Cyprus», International Journal of Sociology and Social Policy, Vol. 26 No 7/8, pp. 295-308.

Arasli, H. and Tumer, M. (2008), «Nepotism, favoritism and cronyism: A study of their effects on job stress and job satisfaction in the banking industry of north Cyprus», Social Behavior \& Personality: An International Journal, Vol. 36 No 9, pp. 1237-1250.

Barnhart, R. K., (Ed,), «Cronism», Dictionary of Etymology. The Orgins and Development of over 25.000 English Words, Hodder \& Stoughton, New York, p. 128.

Barnhart, R. K., (Ed,), «Nepotism», Dictionary of Etymology. The Orgins and Development of over 25.000 English Words, Hodder \& Stoughton, New York, $p$.

Botelho, C. (2017), "The Role of Human and Social Capital on the Influence of HR Practices on Organizational Performance», in Lopes, I. T. and Serrasqueiro, R. (Ed.), EC/C 2017-9th European Conference on Intellectual Capital, Academic Conferences and Publishing Limited, Lisbon, pp. 26-33.

Bourdieu, P. (1983), „The forms of capital», in Richardson, J. (Ed.), Handbook of Theory and Research for the Sociologu of Education, Greenwood Press, New York, NY, pp. 241-258.

Brickson, S. L. (2007), "Organizational identity orientation: the genesis of the role of the firm and distinct forms of social value», Academy of Management Review, Vol. 32 No 3, pp. 864-888.

Bubolz, M. M. (2001), «Family as source, user, and builder of social capital», The Journal of Socio-Economics, Vol. 30 No 2 , pp. 129-131.

Chen Chao C., Chen Xiao-Ping and Huang Shengshed (2013), «Chinese Guanxi. An Integrative Review and New Directions for Future Research», Management and Organization Review, Vol. 9 No 1, pp. 167-207.

Chen Xi, Lans, R. van der, Phan, T. Q. (2017), «Uncovering the Importance of Relationship Characteristics in Social Networks: Implications for Seeding Strategies», Journal of Marketing Research, Vol. 54 No 2, pp. 187-201.

Chmielecki, M. and Sulkowski, L. (2018), "Cultural Factors of Trust in a Public Organization as a Workplace», in Kozuch, B.,

Magala, S. and Paliszkiewicz, J. (Eds), Managing Public Trust, Cham, Palgrave Macmillan, pp. 99-114.

Cobb A. T. (2012), Leading Project Teams. The Basics of Procect Management and Team Leadership, Sage, Los Angeles.

Cohen, D. and Prusak, L. (2001), In Good Company: How Social Capital Makes Organizations Work. Harvard Business Press, Cambridge.

98.

Coleman, J. S. (1988), «Social Capital In the Creation of Human Capital», American Journal of Sociology, Supplement 94, p.

Crowther, J (Ed.), (1998), «Crony», Oxford Advanced Learner's Dictionary of Current English. $5^{\text {th }}$ ed., Oxford University Press, Oxford, p. 277

Crowther, J. (Ed.), (1998), «Nepotism», in Oxford Advanced Learner's Dictionary of Current English. $5^{\text {th }}$ ed., Oxford University Press, 1998, p. 779.

Eroglu, I. and Kangal N. (2016), „Can Social Capital Be the New Dynamics of Economic Development?», Annales. Etyka w

Zyciu Gospoarczym/Annales. Ethics in Economic Life, Vol. 19 No 4, pp. 51-66.

Ewing, D. W. (1965), «ls nepotism so bad?», Harvard Business Review, Vol. 43 No 1, pp. 22-160 
G. Ignatowski, B. Stopczynski, J. Trebska. Paradox of Nepotism in Enterprises in Poland and Ukraine: Social Capital Perspective

Ferragina, E. and Arrigoni, A. (2017), «The Rise and Fall of Social Capital: Requiem for a Theory?», Political Studies Review, Vol. 15 No 3, pp. 355-367.

Fisher, C. D. (2005), «Nepotism policies», in C. L. Cooper C. L. (Ed.), The Blackwell Encyclopedia of Management, vol. 5, 2nd ed., Blackwell Publishing, Oxford, p. 252.

Fu, I-Pang., (2015), «Favoritism: Ethical Dillemas Viewed Through Multiple Paradigms», The Journal of Values-Based Leadership, Volume 8 No 1, p. 1-7.

Gevrek, D., Gevrek, Z. E. (2010), «Nepotism, Incentives and the Academic Success of College Students», Labour Economics, Vol. 17 No 3, pp. 581-591.

Hanka, M.J., Engbers, M.T (2017), «Social Capital and Economic Development: A Neighborhood Perspective», Journal of Public and Nonprofit Affairs, Vol. 3 No 3, pp. 272-291.

Inkpen, A. C. and Tsang, E. W. (2005), «Social Capital, Networks, and Knowledge Transfer», Academy of Management Review, Vol. 30 No 1, pp. 146-165.

Jaskiewicz, P., Uhlenbruck, K., D., Balkin, D. B. and Reay, T., "Is Nepotism Good or Bad? Types of Nepotism and Implications for Knowledge Management», Family Business Review, Vol. 26 № 2, pp. 121-139.

Jones, I. W., Nyland, C. M. and Pollitt, M. G. (2001), How Do Multinationals Build Social Capital? : Evidence from South Africa. ESRC Centre for Business Research, University of Cambridge, Cambridge.

Jones, R. G. and Stout T. (2015), «Policing Nepotism and Cronyism Without Losing the Value of Social Connection», Industrial and Organizational Psychology, Vol. 8 No 1, pp. 2-12.

Keely, B. (2007), Human Capital, OECD, Paris.

Keles, H. N., Ozkan, T. K. and Bezirci, M. (2011), «A Study On The Effects Of Nepotism, Favoritism And Cronyism On Organizational Trust In The Auditing Process In Family Businesses In Turkey», International Business \& Economics Research Journal, Vol. 10 No 9, pp. 9-16.

Kramarz, F., Skans, O. N. (2007), «With a Little Help from my ... Parents? Family Networks and Youth Labor Market Entry», available at: https://conference.nber.org/conferences/2007/si2007/EFABG/kramarz.pdf/ (accessed 6 Mai 2019), pp. 24.

Lin, N. (2017), "Building a network theory of social capital», in Lin, N., Cook, K. and Burt, R. S. (Eds), Social capita/,Routledge, New York NY, pp. 3-28.

Lin, Shu-hui, Hu, Sching-yang. (2007), «A Family Member or Professional Management? The Choice of a CEO and Its Impact on Performance», Corporate Governance, Vol 15 No 6, pp. 1348-1362.

Luo, Y., Huang, Y. and Wang, S. L. (2012), «Guanxi and Organizational Performance: A Meta-Analysis», Management and Organization Review, Vol. 8 No 1, pp. 139-172.

Miller, D., Wright, M., Le Breton-Miller, I., Scholes, I. (2015), «Resources and Innovation in Family Businesses: The Janus-

Face of Socioemotional Preferences», California Management Review, Vol. 58 No 1, pp. 20-40. Nadeema, M., Ahmadb, R., Ahmadc, N., Batoold, S. R. and Shafique, N. (2015), «Favoritism, nepotism and cronyism as predictors of job satisfaction: Evidences from Pakistan», Journal of Business and Management Research, Vol. 8, pp. 224-228.

Nahapiet, J. and Sumantra, G. (2000), «Social Capital, Intellectual Capital, and the Organizational Advantage», in Lesser, E.

L. (Ed.), Knowledge and Social Capital: Foundations and Applications, Butterworth, Boston, pp.119-157.

Mutz, D. C. (2005), «Social Trust and E-Commerce: Experimental Evidence for the Effects of Social Trust on Individuals economic behavior», Public Opinion Quarterly, Vol. 69 No 3, pp. 393-416.

Onoshchenko, O., Williams, C. C. (2014), «Evaluating the role of blat in finding graduate employment in post-Soviet Ukraine

The «dark side» of job recruitment?», Employee Relations, Vol. 36 № 3, .pp. 254-265.

Qaisar, I. (2016), «Preferential Treatment: An Empirical Study in Education Sector of Pakistan», International Journal of

Management, Accounting \& Economics, Vol. 3 No 9, pp. 490-493.

Padgett M. Y., Morris K. A. (2005), «Keeping it «All in the Family:» Does Nepotism in the Hiring Process Really Benefit the Beneficiary?», Journal of Leadership and Organizational Studies, Vol. 11 No. 2, pp. 34-45.

Padgett, M. Y., Padgett, R. J. and Morris, K. A. (2015), «Perceptions of Nepotism Beneficiaries: The Hidden Price of Using a

Family Connection to Obtain a Job», Journal of Bussiness and Psychology, Vol. 30, No. 2, pp. $283-298$.

Partridge E. (1991), Origins. An etymological dictionary of Modern English, Routrledge \& Kegan Paul Ltd, London.

Perez-Alvarezy, M., Strulik, H., «Nepotism, Schooling Outcomes and Economic Development», CSAE Working Paper Series

2018-02, Centre for the Study of African Economies, University of Oxford.

Ponzo, M., Scoppa, V. (2010), «A Simple Model of Nepotism», Working Paper n. 17 - 2010, Università della Calabria,

Dipartimento di Economia e Statistica.

Popczyk, W. (2017), Family Social Capital Versus Nepotism in Family Businesses, RSEP International Conference on Social

Issues and Economic Studies, Ankara, BC GRUP INC, pp. 47-52.

Reagans, R. and Zuckerman, E. W. (2001), «Networks, Diversity, and Productivity: The Social Capital of Corporate R\&D

Teams», Organization Science, Vol. 12 № 4, pp. 502-517.

Riggio, R. R. and Saggi, K. (2005), «lf We Do Our Job Correctly, Nobady Gets Hurt by Nepotism», Industrial ond Organizational Psychology, Vol. 8 No 1, pp. 19-21.

Sabatini, F. (2007), «The Role of Social Capital in Economic Development», Working Paper n. 43 giugio 2007, Facoltà di Economia Università di Bologna Sede di Forli. 
G. Ignatowski, B. Stopczynski, J. Trebska. Paradox of Nepotism in Enterprises in Poland and Ukraine: Social Capital Perspective

Scholar Google (2018), Social Capital, available at www.scholar.google.com (accessed 29 November 2018).

Sidani, Y. and J. Thornberry, J. (2013), «Nepotism in the Arab World: An Institutional Theory Perspective», Business Ethics Quarterly, Vol. 23 No 1, pp. 69-96.

Sroka, W., Vveinhardt, J. (2018), «Nepotism and favouritism in the steel industry: a case study analysis», Forum Scientiae Oeconomia, Vol. 6 No 1, pp. 31-45.

Stec M. (2009), «Innovation in European Union Countries», Gospodarka Narodowa, Vol. 20 No 11-12, pp. 45-65.

Sulkowski, L. (2017), «Social Capital, Trust and Intercultural Interactions», in Rozkwitalska, M., Sulkowski, L. and Magala, S. (Eds), Intercultural Interactions in the Multicultural Workplace: Traditional and Positive Organizational Scholarship, Springer, Cham, pp. 155-171.

Vveinhardt, J. and L. Petrauskaite L. (2013), «Intensity of Nepotism Expression in Organizations of Lithuania», Management of Organizations: Systematic Research, № 66, pp. 129-144.

Whetten, D. A. (2006), «Albert and Whetten revisited: Strengthening the concept of organizational identity», Journal of Management Inquiry, Vol. 15 № 3, pp. 219-234.

Williams, C. and Bezeredi, S. (2017), «Evaluating The Use Of Personal To Bypass Formal Procedures: A Study of Vrski In Republic of Macedonia», UTMS Journal of Economics, Vol. 8 No 2, pp. 169-182.

Williams, C. C. and Onoshchenko, O. (2014), «Evaluating the prevalence and nature of blat in post-Soviet societies A case study of the education sector in Ukraine», International Journal of Social Economics, Vol. 41 No 9, pp. 749-759.

Williams, C. C. and Yang, J. (2017), «Evaluating the use of personal networks to circumvent formal processes: acase study of vruzki in Bulgaria», South East European Journal of Economics \& Business, Vol. 12 № 1, pp. 57-67.

Williams, M., L. and Laker, D. (2010), «Nepotism: Can it Affect the Bottom Line?», in Bolloit, J. D., Johns, T. R. and Myers, C. (Ed.), NABET. Northeastern Association Of Business, Economics, and Technology 2010. Proceedings of the 33th Annual Meeting October 19th \& 20th, 2010, available at http://nabet.us/Archives/2010/NABET\%20Proceedings\%202010.pdf\#page=238/ (accessed 1 January 2019), pp. 230-236.

Woolcock, M. and Narayan, D. (2000), «Social Capital: Implications for Development Theory, Research, and Policy», The World Bank Research Observer, Vol. 15 No 2, pp. 225-249.

Гжегож Ігнатовські, D.SC., Соціальна академія наук у Лодзі (Польща);

Варфоломій Стопщинські, D.SC., Соціальна академія наук у Лодзі (Польща);

Джоанна Требська, D.SC., Лодзинський університет (Польща).

Парадокс непотизму на підприємствах Польщі та України: перспективи соціального капіталу

Головною метою статті $\epsilon$ аналіз непотизму як феномену та його впливу на діяльність малих та середніх підприємств (МСП) Польщі та України, а також оцінка його негативного впливу на соціальний капітал. Систематизація наукових напрацювань з означеної проблематики засвідчила, що у східноєвропейських країнах проблема непотизму $\epsilon$ розповсюдженою. При цьому непотизм негативно впливає на діяльність МСП та спричинюе погіршення рівня мотивації працівників та їх задоволення роботою. Окрім цього, за таких умов рівень відповідальності працівників $є$ також низьким. Авторами зазначено, що відбір менш ефективних кандидатів на робоче місце $\epsilon$ причиною низького рівня продуктивності працівників. Однак, на основі результатів систематизації літературних джерел, авторами встановлено, що непотизм іноді може мати позитивний вплив на підприємства сімейної форми власності (family business). У статті висвітлено взаємозв'язок соціального капіталу та непотизму на прикладі МСП Польщі та України. Вибірку даного дослідження сформовано на основі опитування 691 студентів заочного відділення, які навчаються у приватних університетах Польщі у період із лютого по травень 2019 року. На основі отриманих результатів емпіричного аналізу, авторами зазначено, що непотизм та система "свої людей» є поширеними явищами як в Польщі, так і в Україні. Однак, авторами наголошено, що в Україні вони $\epsilon$ більш розповсюдженими. Так, непотизм та система "своїх людей» негативно впливає на рівень задоволення роботою, мотивації, відповідальність та довіру працівників. Крім того, одним із важливих наслідків $є$ зниження соціального капіталу підприємства, який є одним із суттєвих факторів його розвитку. Таким чином, результати дослідження мають практичне значення для менеджерів компанії. Крім цього, отримані результати можуть сприяти створенню та організації прозорих процесів рекрутингу та ефективного управління персоналом підприємства.

Ключові слова: непотизм, система «своїх людей», соціальний капітал, рекрутинг.

Manuscript received: 19.03.2019.

(C) The author(s) 2019. This article is published with open access at Sumy State University. 